\title{
КОНКУРЕНТНА СПРОМОЖНІСТЬ ПІДПРИЕМСТВ ДЛЯ ЕКОНОМІЧНОЇ СТАБІЛЬНОСТІ ТА ПЕРЕДБАЧУВАНОСТІ
}

\author{
Пекна Галина Борисівна, \\ кандидат економічних наук, дочент, \\ дочент кафедри теоретичної та прикладної економіки, \\ ВНЗ «Університет економіки та права «КРОК», \\ ORCID: https://orcid.org/0000-0003-4902-6052
}

Анотація. Розділ присвячено дослідженню явища конкурентної спроможності підприємств під кутом зору її зв'язку зі стабільністю й передбачуваністю результатів діяльності. Економіка окремих підприємств, як і загалом національна економіка, має оцінюватися за певними критеріями визначеності та стабільності. Саме конкурентна спроможність стає важливою передумовою визначеності, стабільності підприємства, а отже, й передбачуваності результатів. Такий підхід набуває актуальності в умовах сучасної зростаючої економічної невизначеності. Для його практичної реалізації доцільно уточнити зміст поняття (явища) конкурентної спроможності на різних рівнях ії̈ здійснення та дослідити способи ії оцінювання.

Ключові слова: конкурентна спроможність підприємства, товару, галузі, економіки, методи оцінювання конкурентної спроможності.

Швидкі неочікувані зміни кон'юнктури національного та світового ринків, перманентні зміни технологій, особливо, у сфері комунікацій, часто діють не на користь суб'єктів підприємницької діяльності. Підприємства, що функціонують в умовах високого рівня невизначеності та неочікуваних впливів, $є$ найбільш загроженими. Для протидії загрозам необхідні механізми швидкого реагування на зміни. Йдеться про те, що сьогодні називають «управління змінами» й що корелює 3 формуванням конкурентної спроможності підприємства.

Сучасні стратегії забезпечення конкурентної спроможності підприємств покликані вирішувати об'єктивно існуючу суперечність. Це - суперечність між досягненням максимальної стабільності та ефективності використання ресурсів у поточному періоді, з одного боку, та формуванням передумов для змін у майбутньому - з іншого. У цьому, на наш погляд, насамперед має виявлятися конкурентна спроможність підприємств за умов невизначеності.

На жаль, підхід до конкурентної спроможності на засадах вирішення суперечності між «завданням на сьогодні» та «завданням для майбутнього» не віддзеркалено в українському законодавстві. Зокрема, за Законом України «Про захист економічної конкуренції», остання потрактована лише як здобута перевага над іншими. У Законі 
зазначено: «Економічна конкуренція (конкуренція) - змагання між суб'єктами господарювання 3 метою здобуття завдяки власним досягненням переваг над іншими суб'єктами господарювання, внаслідок чого споживачі, суб'єкти господарювання мають можливість вибирати між кількома продавцями, покупцями, а окремий суб'єкт господарювання не може визначати умови обороту товарів на ринку» [1]. Як свідчить наведена стаття Закону, економічна конкуренція розглядається лише як боротьба, змагання, суперництво з іншими за переваги на ринку.

Інші чинні закони - Закон України «Про захист від недобросовісної конкуренції», Закон України «Про застосування спеціальних заходів щодо імпорту в Україну» - акцентують увагу на способах регламентації економічної діяльності. Ці нормативні документи не створюють підгрунтя для формування інструментарію для вирішення суперечності між стабільністю та мінливістю [2; 3].

У науковому обігу циркулюють різні визначення конкуренції, наповнені дещо відмінним змістом. У нашому дослідженні зміст поняття «конкуренція» $є$ особливо важливим. Адже від того, який зміст вкладено в це поняття, залежить і зміст поняття «конкурентна спроможність».

Спеціальні дослідження, присвячені проблемі еволюції поняття «конкуренція», дають підстави для деяких важливих узагальнень. Такі дослідження здійснюються, зокрема, й вітчизняними науковцями [4]. 3 усього масиву визначень конкуренції, на наш погляд, необхідно виокремити дві групи, а саме:

- визначення, що розкривають необхідні умови функціонування ринку як конкурентного й стосуються кількості виробників і споживачів, які діють на ринку, а також свободи входження на ринок та виходу з нього;

- визначення, в яких акцентується увага на інструментах (способах реалізаиіï) перемоги у конкурентній боротьбі.

При більш детальному аналізі змісту поняття «конкуренція», 3'ясовується, що в якості ії проявів розглядаються, крім традиційних, які виявляються у суперництві, й інші, а саме:

- динамізм економіки, постійне впровадження нових технологій у виробництво, управління та комунікації зі споживачами та партнерами, формування нових організаційних структур;

- максимізація прибутку на основі додаткових витрат, пов'язаних 3 дослідженнями ринків та створенням інноваційних форм просування власного товару;

- прагнення убезпечитися від негативних наслідків ринкового суперництва з відповідним діями, спрямованими на змову між колишніми конкурентами та на монополізацію ринку, що актуалізує примусові антимонопольні дії урядів для захисту конкурентного середовища.

Як відомо, конкуренція постійно модифікується, набуваючи нових форм. Класик теорії конкуренції М. Портер виокремлює п'ять 
рушійних сил конкуренції, під впливом яких відбуваються ії зміни. Показово те, що серед цих рушіїв акцентовано потенційні загрози бути витісненими 3 ринку більш успішними виробниками. Виокремлено також чинник створення іншими виробниками товарів-замінників 3 кращими або новими споживчими властивостями [5]. Зрозуміло, що згадані рушійні сили конкуренції формують економічну невизначеність підприємства. Адже достатньо важко й, здебільшого, неможливо передбачити дії інших «гравців ринку».

Ми вважаємо принципово важливим те, що конкуренція - це відносини з ознаками постійних змін у формах та способах ведення бізнесу, з ризиками невизначеності. Тому конкурентна спроможність це здатність діяти саме в таких мінливих, ризикових умовах, які передбачають додаткові витрати, пов'язані не просто з суперництвом, а й 3 пристосуванням до мінливого середовища. У цьому сенсі конкурентна спроможність підприємства постає не стільки як суперництво 3 іншими «гравцями» ринку, скільки як «суперництво 3 самим собою». Йдеться про суперечність між підприємством у його старому (традиційному) стані й ним же у новому стані. При цьому, новий стан має відповідати новим умовам провадження бізнесу, новим технологіям та потребам. Це - особливе діалектичне заперечення новим станом підприємства його старого стану, яке і $є$ розвитком.

Пропоноване нами визначення конкурентної спроможності відповідає завданню цього розділу - дослідити конкурентну спроможність підприємства під кутом зору економічної невизначеності. Однак, існують інші визначення конкурентної спроможності, які сформувалися в інших контекстах. Саме такі інші контексти вимагали інших акцентів у визначеннях конкурентної спроможності.

Конкурентна спроможність підприємства у багатьох дослідженнях асоціюється (пов'язується) 3 конкурентною спроможністю товарів, конкурентною спроможністю галузей (секторів) економіки та 3 конкурентною спроможністю всієї національної економіки. Цей зв’язок може бути поданий у такий спосіб (рис. 1).

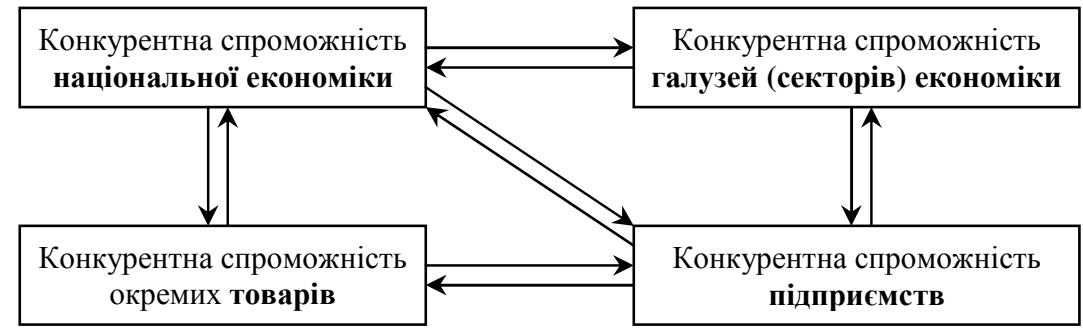

Рис. 1. Взаємозв'язок рівнів конкурентної спроможності Джерело: створено автором самостійно. 
На рис. 1 ілюстровано ідею взаємної залежності чотирьох рівнів (проявів) конкурентної спроможності, а саме: всієї національної економіки, іiї галузей (секторів), підприємств та окремих товарів.

Конкурентна спроможність окремого підприємства, яка $\epsilon$ об'єктом нашого дослідження, формується під впливом конкурентної спроможності галузі. У той же час, конкурентна спроможність кожного підприємства формує конкурентну спроможність галузі, в якій вони функціонують. Остання, природно, збільшується зі збільшенням кількості конкурентоспроможних підприємств.

Конкурентна спроможність підприємства реалізується через конкурентну спроможність створюваних ним товарів. I, навпаки, конкурентна спроможність товарів формує конкурентну спроможність підприємства.

Ще однією лінією зв'язку конкурентної спроможності підприємства є іiї залежність від конкурентної спроможності національної економіки. Остання, за нашим уявленням, відіграє роль своєрідного «зовнішнього середовища» сприяння конкуренції на всіх рівнях.

3 аналізу українських досліджень у царині проблем конкурентної спроможності підприємства можна зробити такий висновок. Достатньо часто вона визначається та оцінюється через конкурентну спроможність створюваних товарів [6; 7]. Рідше конкурентна спроможність підприємства пов'язується у визначеннях та оцінках з конкурентною спроможністю галузі та усієї національної економіки [8].

Погоджуючись з ідеєю пов' язаності понять (явищ) конкурентної спроможності економіки, галузі, підприємства та окремого товару, ми вважаємо доцільним якомога більш чітке їх розмежування. Йдеться про з'ясування не лише спільного, а й особливого (відмінного) у змісті цих понять. Лише у такий спосіб може бути створене підгрунтя для розробки конкретних методик оцінювання різних рівнів конкурентної спроможності.

3 огляду на необхідність уточнення змісту конкурентної спроможності підприємства, галузі та окремого товару, зробимо деякі узагальнення.

Конкурентна спроможність галузі здебільшого пов'язується 3 наявністю в ній умов для створення інноваційної продукції та 3 упровадженням продуктів сектору досліджень та розробок (R\&D) [9; 10]. Економетричне оцінювання рівня конкурентної спроможності галузі часто здійснюється з використанням ідей моделі Портера (Porter's diamond mode) [11].

Зрозуміло, що конкурентна спроможність певної галузі може визначатися та оцінюватися порівняно з:

а) подібними галузями в інших національних економіках;

б) іншими галузями власної національної економіки. 
3 огляду на можливість оцінювання конкурентної спроможності галузі на тлі подібних галузей в інших економіках, для більшості країн світу актуальним $\epsilon$ не власне факт перемоги, а здатність брати участь у суперництві. Тобто, йдеться про здатність посідати достойне місце у світовій ієрархії подібних галузей. Така здатність галузі, на наш погляд, може оцінюватися принаймні за такими показниками, як:

- співвідношення внутрішніх та зовнішніх цін на продукцію галузі $\left(P_{d} / P_{f}=k_{P}\right)$;

- інвестиційна привабливість галузі для зовнішніх інвесторів, оцінювана за співвідношенням рівнів доходності інвестицій, тобто процентів на вкладений капітал за кордоном та всередині країни $\left(i_{d} / i_{f}=k_{i}\right)$;

- частка галузі у формуванні пропозиції на міжнародному ринку продукції цієї галузі $\left(S_{d} / S=d_{S}\right)$.

3 використанням пропонованих показників міг би розраховуватися індекс зовнішньої конкурентної спроможності галузі ( $\left.I_{C o m p / i}^{E x t}\right)$. При цьому нормування фактичних значень трьох визначених нами показників $\left(k_{P}, k_{i}, d_{S}\right)$ на тлі подібних значень показників обраної для порівняння групи країн могло б здійснюватися за формулою [1]:

$$
y_{i}=\left(x_{\text {краме }}-x_{\text {факт }}\right) /\left(x_{\text {краме }}-x_{\text {гірие }}\right) \text {, }
$$

де, $\mathrm{y}_{\mathrm{i}}-$ нормоване значення фактичного показника, $x_{\text {факт }}, x_{\text {краще }}, x_{\text {zipuе - }}$ відповідно, фактичне значення показника досліджуваної країни, краще значення показника в групі країн, що відібрана для порівняння, гірше значення показника в групі країн, відібраних для порівняння.

Вагові коєфіцієнти при трьох показниках $-k_{P}, k_{i}, d_{S}-$ для розрахунку інтегрального індексу могло б визначатися 3 використанням поширених прийомів: або шляхом експертного оцінювання, або статистичним методом головних компонент.

Конкурентна спроможність галузі на тлі інших галузей власної національної економіки, тобто внутрішня конкурентна спроможність галузі, може оцінюватися, наприклад, за такими показниками:

- часткою галузі у створенні доданої вартості (ВВП) національної економіки $\left(Y_{i} / Y=d_{Y i}\right)$;

- часткою інноваційної продукції у структурі виробництва галузі $\left(Y_{I n} / Y_{i}=d_{Y i / I n}\right)$;

- продуктивністю праці в галузі $\left(Y_{i} / L_{i}=k_{Y / L}\right)$;

- середньою рентабельністю підприємств галузі $\left(R^{*}\right)$.

За потреби розрахунку індексу внутрішньої конкурентної спроможності галузі міг би застосовуватися той же підхід, що й при визначенні зовнішньої конкурентної спроможності. Логіка нормування показників мала б бути тією ж з єдиною відмінністю. Тут мали б порівнюватися не показники подібних галузей різних країн, а показники різних галузей національної економіки. Залежно від покладених в 
основу оцінювання принципів, для порівняння могли би братися або всі галузі економіки, або галузі, технологічно найближчі до досліджуваної. Вагові коєфіцієнти при чотирьох згаданих показниках при розрахунку інтегрального індексу могли б також оцінюватися 3 використанням поширених прийомів статистичного аналізу.

Конкурентна спроможність товару здебільшого трактується як його здатність задовольняти попит споживачів, виявляючи конкурентні переваги над іншими товарами через:

- споживчі властивості, технічні характеристики, іміджеві ознаки;

- відносний (на тлі імпортованих товарів та вітчизняних товарівзамінників) рівень цін;

- тривалість присутності товару на ринку тощо.

3 огляду на зв'язок конкурентної спроможності підприємства 3 конкурентною спроможністю галузі та створюваних товарів, доречне таке уточнення. Конкурентна спроможність підприємства - це його здатність до змагання за частку ринку, до вирішення суперечності між поточним і необхідним майбутнім потенціалом, яка формується конкурентною спроможністю галузі та створюваних ним товарів.

Принципово важливим $є$ питання зв'язку між конкурентною спроможністю підприємства й конкурентною спроможністю національної економіки. На наш погляд (і це віддзеркалено на рис. 1), конкурентна спроможність національної економіки пов'язана 3 конкурентною спроможністю підприємства й опосередковано, й безпосередньо.

Напрямки безпосереднього впливу конкурентної спроможності національної економіки на конкурентоспроможність підприємства виявляються, зокрема, в структурі індексу глобальної конкурентної спроможності $\left(I_{G C I}\right)$.

Як відомо, індекс глобальної конкурентоспроможності (The Global Competitiveness Index) щороку визначається міжнародною організацією Всесвітнім економічним форумом (ВЕФ) - для всіх країн світу. Це дає можливість сформувати рейтинг країн. Саме місце кожної країни в цьому рейтингу й віддзеркалює рівень іiї національної економічної конкурентної спроможності. Індекс $\left(I_{G C I}\right)$ має високий рівень довіри, оскільки формується за прозорою методикою 3 використанням загальнодоступних статистичних даних і результатів глобального соціологічного опитування. Останнє $є$ щорічним дослідженням ВЕФ разом з мережею партнерських організацій - провідних дослідницьких інститутів світу.

Індекс глобальної конкурентоспроможності розраховується за 12 напрямками оцінювання. Саме перелік та зміст цих напрямків оцінювання $є$ принципово важливим для нашого дослідження. Індекс $\left(I_{G C I}\right)$ охоплює такі структурні елементи - напрямки оцінювання 3 використанням набору показників: 
- макроекономічна стабільність;

- споживчий ринок;

- ринок праці;

- фінансова система;

- розмір внутрішнього ринку;

- якість інститутів;

- стан інфраструктури;

- рівень проникнення IT і сучасних комунікацій;

- здоров'я населення;

- освіта і навички;

- динаміка бізнес-розвитку;

- здатність до інноваиій.

На наш погляд, більшість зі згаданих 12-х напрямків оцінювання конкурентної спроможності національної економіки може тлумачитися як напрямки впливу на конкурентну спроможність окремого підприємства. Це передусім ті 3 них, які сприяють стабільності й вищому рівню визначеності результатів діяльності підприємства. До них ми відносимо: макроекономічну стабільність, фінансову систему, якість інститутів, стан інфраструктури, здатність до інновацій.

У рейтингу, за індексом глобальної конкурентоспроможності, Україна посідає місця, нижчі від середнього рівня. Динаміка місця нашої країни у світовому рейтингу ілюстрована на рис. 2.

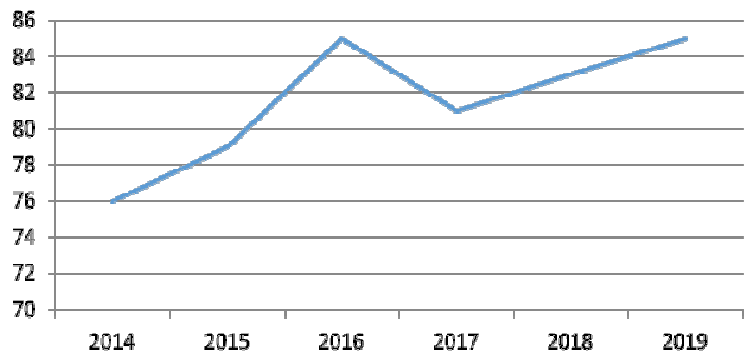

Рис. 2. Україна в міжнародному рейтингу конкурентоспроможності Джерело: власна розробка автора на основі джерела [12].

Як свідчить інформація, ілюстрована на рис. 2, у період 2014 2019 рр. найкращим було 77 місце України в рейтингу економічної конкурентної спроможності. У подальшому було втрачено 8 позицій рейтингу.

Важливим для аналізу загальної економічної конкурентної спроможності є оцінювання на тлі інших країн - компаративний аналіз «найближчого оточення» в рейтингу. Такий аналіз можна здійснити 3 використанням і загальної інформації, поданої на рис. 3. 


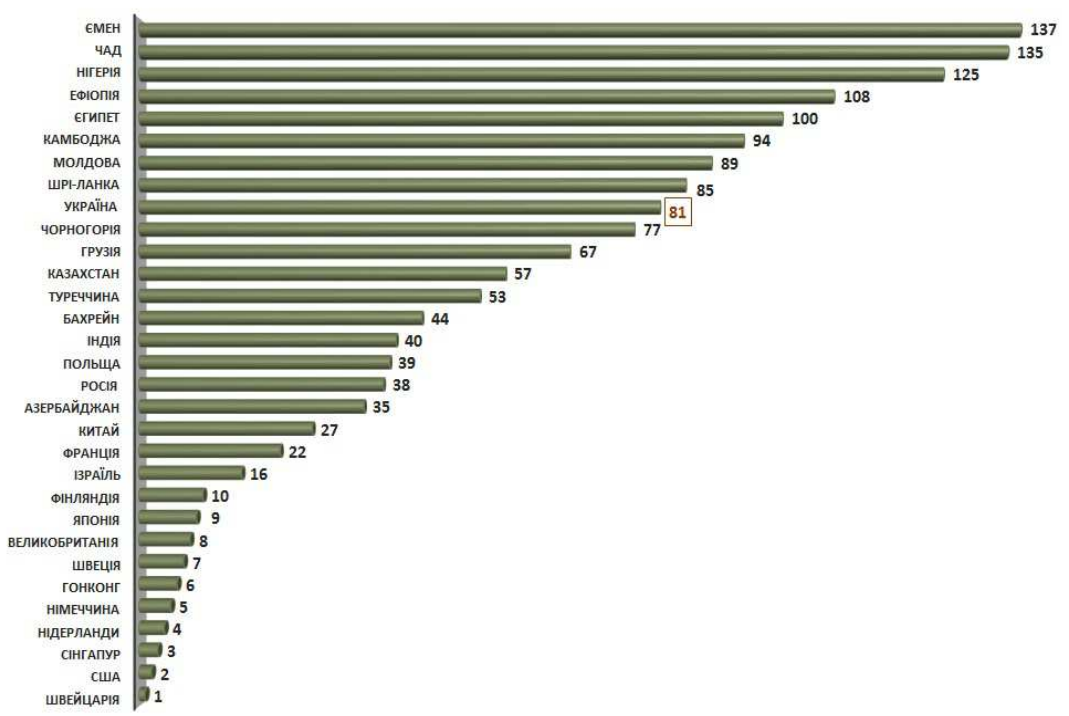

Рис. 3. Позиція України у світовому рейтингу, за індексом глобальної економічної конкурентоспроможності $\left(I_{G C I}\right)$ Джерело: [13].

За інформацією 3 рис. 3, перебуваючи у нижчій половині рейтингу, українська економіка відстала від переважної більшості постсоціалістичних країн, демонструючи гірші показники.

Принципово важливим для аналізу конкурентної спроможності $\epsilon$ ідентифікація причин погіршення місця країни у світовому рейтингу. До прикладу, в 2018 році, посівши загальне 81 -е місце у рейтингу $I_{G C l}$, Україна мала кращі місця за такими конкретними напрямками:

- 46-е - за рівнем освіти;

- 58-е - за рівнем інноваційних можливостей;

- 66-е -за станом ринку праці;

- 77-е місце за рівнем проникнення сучасних технологій.

Натомість, гіршими від загального значення місця України у рейтингу були показники за такими напрямками:

- 94-е - за станом охорони здоров'я;

- 110-е - за рівнем розвитку державних інститутів;

- 131-е - за рівнем макроекономічної стабільності.

Оскільки, незаперечно, існує зв'язок загальної конкурентної спроможності національної економіки та конкурентної спроможності підприємства, то передбачення щодо спроможності окремих підприємств мали б враховувати принаймні такі обставини:

- динаміку національної конкурентоспроможності; 
- зміни впливів окремих напрямків, відповідно, показників на покращення або, навпаки, погіршення місця країни у світових рейтингах конкурентоспроможності.

Для кількісного оцінювання конкурентної спроможності підприємств, 3 використанням певних методик, доцільно дослідити акценти у визначеннях цього явища. 3 огляду на акценти, можна виокремити такі підходи до змісту конкурентної спроможності підприємства:

- $з$ позиції залежності від конкурентної спроможності створюваних товарів;

- 3 позиції залежності від конкурентної спроможності галузі та всієї національної економіки;

- 3 позиції рівня ефективності використання ресурсів;

- $з$ позиції формування людського капіталу;

- 3 позиції змагальності з іншими операторами ринку;

- $з$ позиції здатності до адаптації в конкретних умовах.

Використовувані на практиці методики оцінювання конкурентної спроможності підприємств здебільшого спираються на згадані підходи або на їх окремі фрагменти.

3 великої сукупності методів оцінювання конкурентної спроможності підприємства можна, за певними критеріями, виокремити їх групи (рис. 4).

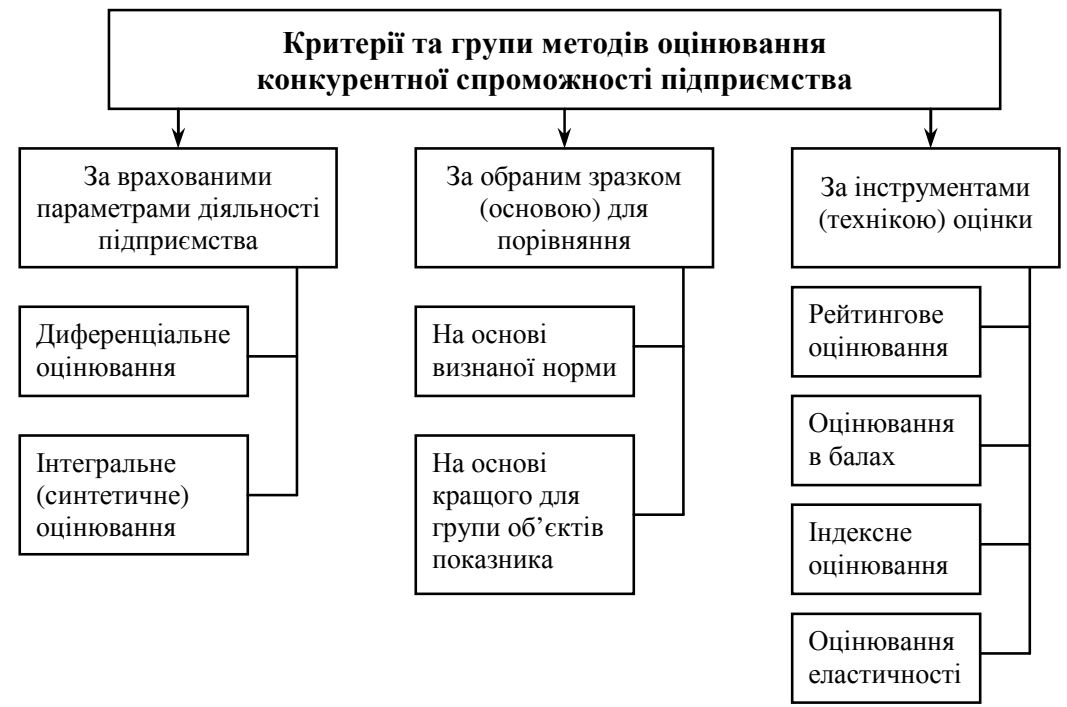

Рис. 4. Критерії та групи методів оцінювання конкурентної спроможності підприємства

Джерело: створено автором самостійно. 
На рис 4. ілюстровано поділ методів оцінювання конкурентної спроможності підприємств за трьома критеріями. За першим критерісм врахованими параметрами діяльності підприємства - виокремлено диференціальні та інтегральні методи. За другим критерієм - обраним зразком - подано методи 3 використанням визнаної норми і 3 використанням кращого показника по групі об'єктів. За третім критерісм - застосованою технікою оцінки - виокремлено методи рейтингового, бального, індексного оцінювання та оцінювання еластичності. Важливо те, що кожний конкретний метод оцінювання конкурентної спроможності підприємства може одночасно належати до декількох груп, відповідаючи декільком критеріям. Це підтверджується аналізом конкретних, застосовуваних в аналізі конкурентної спроможності підприємства методів.

Попри відмінності методів оцінювання конкурентної спроможності підприємства, здебільшого вони грунтуються на ідеї бенчмаркінгу оцінювання (визначення рівня) на підставі порівняння. Оцінювання через порівняння може стосуватися різних боків діяльності підприємства. Насамперед ідеться про порівняння якості продукції, продуктивності, обсягів продажу, ринкової частки, прибутковості інвестицій тощо. Порівняння може стосуватися й таких характеристик, як якість управління, ділова репутація, імідж підприємства. Бенчмаркінг конкурентної спроможності підприємства, як явища дуже мінливого, має відбуватися перманентно. Це вимагає релевантної та постійно оновлюваної інформації про різні боки діяльності підприємства.

Основна складність бенчмаркінгу, як підходу до оцінювання через порівняння конкурентоспроможності, пов'язана з вибором основи для порівняння. Йдеться про вибір аналогів (зразків) - об'єктів 3 параметрами діяльності, які приймаються в якості еталону. Якщо порівнювані підприємства суттєво відрізняються за номенклатурою виробів, технологіями, організацією виробництва та управління, стадією життєвого циклу тощо, то порівняння втрачає коректність. Для уникнення некоректності, «еталонний об’єкт» - гіпотетична компанія, наділена певними властивостями, - має визначатися 3 урахуванням вимоги подібності.

Ідея «еталонного об'єкту» має певні переваги, оскільки створює для підприємства певний позитивний образ в якості мети, яку треба досягти. Водночас, фахівці зі стратегічного управління звертають увагу на негативні результати такого підходу. Адже прагнення підприємств «копіювати модель» може спричиняти деформування економічного суперництва та змагального характеру бізнесу. Наслідком цього може ставатися втрата переваг від правдивого (об'єктивного) суперництва між підприємствами для споживачів і для всієї економіки. 
Типовим прийомом у межах оцінювання через порівняння на основі еталону є експертне оцінювання. Цей прийом може давати позитивні результати у випадку фаховості експертів та правильної статистичної обробки одержаних при опитуванні результатів. Завданням експертів може ставати оцінка рівня якогось параметра (здебільшого того, що не має кількісних показників) у балах, рейтингування досліджуваних об'єктів, значущості впливу (вагових коєфіцієнтів при інтегральному оцінюванні) тощо.

Розгляд окремих методів оцінювання конкурентної спроможності підприємств дає підстави для підтвердження дієвості пропонованої нами класифікації методів оцінювання (рис. 4).

При ототожненні конкурентної спроможності підприємства 3 конкурентною спроможністю створюваних ним товарів використовують диференціальний метод. Тобто, здійснюється порівняння окремих параметрів певного товару та товару, обраного в якості зразка (бази) для порівняння. Таке оцінювання $є$ доцільним для будь-якого етапу життєвого циклу товару й життєвого циклу підприємства. При цьому використовується найпростіша формула відносного оцінювання:

$$
q_{i}=\frac{P_{i}}{P_{i 0}} \times 100 \%,(i=1,2,3, \ldots, n),
$$

де $q_{i}$ - окремий показник конкурентної спроможності підприємства по $i$-му товару, оціненому за певним параметрам, наприклад, за економією електричної енергії при споживанні, за якістю дизайну, за надійністю у користуванні тощо; $P_{i}$ - фактичне кількісне значення параметра, за яким оцінюється товар; $P_{i 0}$ - кількісне значення параметра товару, обраного (визнаного) в якості зразка; $n$ - кількість параметрів, за якими оцінюється товар, через який виявляється рівень конкурентної спроможності підприємства.

Якщо здійснюється оцінювання конкурентної спроможності підприємства через окремі економічні параметри стану підприємства, то також може використовуватися формула 1. В якості параметрів можуть досліджуватися продуктивність, частка ринку, рівень рентабельності, темпи економічного зростання тощо. Змінні моделі матимуть такі значення: $P_{i}$ - фактичне значення параметра, за яким оцінюється економічний стан підприємства; $P_{i 0}-$ кількісне значення економічного параметру підприємства, обраного (визнаного) в якості зразка.

Розглянутий метод оцінювання конкурентної спроможності, за класифікацією, презентованою на рис. 4, належить до групи диференціального оцінювання (за першим критерієм), до групи оцінювання за обраним зразком (за другим критерієм), до групи індексних методів (за третім критерієм). 
Висновки про рівень конкурентної спроможності підприємства, за результатами диференціального (за окремими показниками) оцінювання $є$ достатньо простими. До прикладу, таке оцінювання дає можливість зафіксувати, на скільки відсоткових пунктів параметр товару, за яким оцінюється підприємство, відхиляється від зразка. Але такі прості висновки є обмеженими, бо в них ігнорується багато інших важливих аспектів конкурентної спроможності підприємства.

При врахуванні факту багатосторонності явища конкурентної спроможності підприємства використовуються методи інтегрального (комплексного) оцінювання.

Така інтегральність може бути зреалізована навіть при оцінюванні конкурентної спроможності підприємства через один товар. Комплексність досягається у випадку, якщо товар оцінюється не за одним, а за декількома параметрами. Йдеться про використання так званого параметричного індексу споживчих властивостей товару $\left(J_{n}\right)$ [14], що розраховується за формулою:

$$
J_{n}=\sum a_{j} \times i_{j},
$$

де $n$ - кількість аналізованих параметрів; $a_{j}$ - вага $j$-го параметричного індексу, яка зазвичай визначається експертним шляхом; $i_{j}$ - параметричний індекс $j$-го параметра.

При змішаному диференціально-інтегральному підході, тобто при оцінюванні конкурентної спроможності підприємства через певний товар, який оцінюється не за одним, а за декількома параметрами, може бути застосована формула:

$$
q_{i}=\frac{J_{i}}{J_{i 0}} \times 100 \%,
$$

де $J_{n}$ - параметричний інтегральний індекс оцінювання конкретного товару; $J_{n 0}$ - параметричний інтегральний індекс оцінювання товару, обраного в якості зразка.

Інший варіант інтегрального оцінювання конкурентної спроможності може забезпечуватися при використанні особливого індексу, отриманого без нормування індексів окремих параметрів, за формулою:

$$
I_{n p}=q_{i 1} \times q_{i 2} \times q_{i 3} \ldots q_{i n},
$$

де $I_{n p}$ - груповий показник конкурентоспроможності за нормативними параметрами; $q_{i}$ - окремі індексні показники конкурентоспроможності 3 урахуванням нормативів; $n$ - кількість параметрів, що оцінюються.

Особливість методики оцінювання на основі групового індексу (за формулою 4) полягає в тому, що він передбачає однакову важливість 
для конкурентної спроможності підприємства всіх обраних параметрів. Адже неконкурентність хоча б за одним показником, тобто відсутність певного параметру (до прикладу, $q_{i 2}=0$ ), спричиняє нульове значення всього інтегрального індексу.

Оцінювання конкурентної спроможності 3 використанням формул (2) та (4), за класифікацією, поданою на рис. 4, є інтегральним, на основі визнаної норми та з використанням інтегральних індексів.

Конкурентна спроможність підприємства в усіх досі розглянутих нами методах оцінювалася власне за внутрішніми характеристиками підприємства. Йшлося про якості створених товарів та про різні економічні параметри діяльності. Зовнішній аспект діяльності підприємства при цьому був присутній опосередковано, а саме: при визначенні зразка для порівняння. Однак, конкурентна спроможність може оцінюватися й власне через зовнішні параметри. Зокрема, до таких належать параметри реагування споживачів продукції галузі на зміни в окремих аспектах діяльності підприємства. До таких показників (одночасно методів оцінювати), на наш погляд, можуть належати:

- коєфіцієнти $\left(E_{P}^{D}\right)$ еластичності попиту споживачів $(D)$ за цінами тих товарів, якими насамперед підприємство презентоване на галузевому ринку $(P)$ :

$$
E_{P}^{D}=\frac{\Delta D}{\Delta P} .
$$

Стабільні й відносно невисокі значення цього показника еластичності, на наш погляд, можуть бути потрактовані як свідчення стабільної конкурентної позиції підприємства на ринку;

- показники реагування споживачів на рекламні (іміджеві) заходи підприємства, наприклад, у вигляді коєфіцієнта $\left(k_{A d v}^{\mathrm{Rev}}\right)$ зміни обсягів продажів $(\operatorname{Rev})$ на кожну додаткову одиницю рекламних (іміджевих) витрат $(A d v)$ :

$$
k_{A d v}^{\operatorname{Re} v}=\frac{\Delta \operatorname{Re} v}{\Delta A d v} .
$$

Відносно високі та зростаючі значення цього коєфіцієнта можуть тлумачитися як зміцнення конкурентної позиції через більшу довіру до дій підприємства та до поданої ним інформації;

- коєфіцієнти $\left(k_{\text {Inv }}^{P l}\right)$ зміни позиції підприємства в рейтингу підприємств галузі $(P l)$ на кожну додаткову одиницю звичайних інвестиційних або інноваційних витрат (Inv):

$$
k_{I n v}^{P l}=\frac{\Delta P l}{\Delta I n v} .
$$


Позитивні значення цього коєфіцієнта можуть свідчити про перемогу підприємства у змаганні з іншими підприємствами галузі через більш ефективне інвестування. Останнє $є$ безпосереднім проявом більшої конкурентної спроможності підприємства.

Наведені методи оцінювання конкурентної спроможності підприємства через зовнішнє реагування на зміни в його діяльності фактично, оцінювання еластичності - лише за формою $\epsilon$ диференціальними. За змістом, вони інтегральні. Підставою для такого твердження $є$ те, що зовнішнє оточення галузевого ринку реагує на підприємство як на деяку цілісність. У цій цілісності виявляються переплетіння множини параметрів діяльності підприємства, а не лише якійсь один параметр.

\section{Висновки:}

Досліджені теоретичні підходи до тлумачення змісту конкурентної спроможності підприємства формують підгрунтя для уявлень про зв'язок між конкурентною спроможністю та стабільністю й визначеністю особливої економіки цього підприємства. Але суперечність між стабільністю теперішнього стану підприємства та необхідністю змін заради майбутнього, на якій ми акцентували увагу, ще не «вмонтована» в загальну теорію конкурентної спроможності. Тому наукова і прикладна проблема пояснення зв'язку між конкурентною спроможністю та економічною стабільністю й визначеністю на рівні підприємства навряд чи може вважатися вирішеною.

Аналізовані нами методи оцінювання конкурентної спроможності підприємства, на наш погляд, не містять релевантного прикладного інструментарію оцінювання 3 урахуванням економічної невизначеності. Хоча використовувані в аналізі прийоми дають можливість увести параметр невизначеності в методики оцінювання.

Майбутні дослідження в царині конкурентної спроможності підприємства, на наш погляд, доцільно зосередити на двох проблемах: 1) на уточненні уявлень про зв'язок між здатністю брати участь в економічному змаганні та необхідністю пристосування до умов невизначеності; 2) на створенні методик оцінювання конкурентної спроможності з урахуванням параметру невизначеності.

\section{Лimepamypa:}

1. Про захист економічної конкуренції : Закон України від 11 січня 2001 року №2210. Редакція від 11.08.2013, підстава 406-18. Відомості Верховної Ради Украӥни. 2001. №12. С. 64.

2. Про захист від недобросовісної конкуренції : Закон України від 7 червня 1996 р. №236/96-ВР. Відомості Верховної Ради України. 1996. №36. Ст. 164. 
3. Про застосування спеціальних заходів щодо імпорту в Україну : Закон України від 22 грудня 1998 р. Відомості Верховної Ради Украӥни. 1999. №11. Ст. 78.

4. Рибакова О. В. Конкуренція і конкурентоспроможність: економічна суть та фактори підвищення. URL: http://archive.nbuv.gov.ua.

5. Портер Е. Майкл. Конкурентная стратегия: методика анализа отраслей и конкурентов / Пер. с англ. Москва : Альпина Бизнес Букс, 2005. $454 \mathrm{c}$.

6. Жукевич С. М. Конкурентний аналіз в контексті стратегічного управління підприємством. Економічні науки. Сер. : Економіка та менеджмент. 2012. Вип. 9(2). C. 175-182. URL : http://www.irbis-nbuv. gov.ua/cgi-bin/irbis_nbuv/cgiirbis_64.exe?I21DBN=LINK\&P21DBN= UJRN\&Z21ID $=\& S 21 \mathrm{REF}=10 \& S 21 \mathrm{CNR}=20 \& S 21 \mathrm{STN}=1 \& \mathrm{~S} 21 \mathrm{FMT}=\mathrm{ASP}$ _meta\&C21COM=S\&2_S21P03=FILA=\&2_S21STR=ecnem_2012_9(2)_27.

7. Діденко Є. О., Жураківський П. І. Модель управління конкурентоспроможністю підприємства. Ефективна економіка. 2017. №5. URL : http://www.economy.nayka.com.ua/?op=1\&z=5590.

8. Конкурентоспроможність підприємства: оцінка рівня та напрями підвищення : монографія / За заг. ред. О. Г. Янкового. Одеса : Атлант, 2013. $470 \mathrm{c}$.

9. Castellacci F. Innovation and the competitiveness of industries: Comparing the mainstream and the evolutionary approaches. URL : https://www.sciencedirect.com/science/article/pii/S0040162507001692.

10. Kleynhans E. Factors Determining Industrial Competitiveness And The Role Of Spillovers. The Journal of Applied Business Research. 2016. Volume 32. Number 2. URL : https://clutejournals.com/index.php/ JABR/article/download/9594/9689/.

11. Bakan I., Dogan I. Competitiveness of the industries based on the porter's diamond model: an empirical study. URL : https://www.academia.edu/ 33159606/.

12. Державна інноваційна фінансово-кредитна установа (SFII). URL : www.sfii.gov.ua.

13. Україна в рейтингах: як змінювалися позиції країни в 20142019 роках. URL : https://www.slovoidilo.ua/2019/11/01/infografika/ ekonomika/ukrayina-rejtynhax-yak-zminyuvalysya-pozycziyi-krayiny2014-2019-rokax.

14. Лупак Р. Л., Васильців Т. Г. Конкурентоспроможність підприємства : навч. посіб. Львів : Видавництво ЛКА, 2016. 484 с. 